\title{
Hydrologic Conditions in the Bill Williams River National Wildlife Refuge and Planet Valley, Arizona, 2000
}

Water-Resources Investigations Report 02-4214

Prepared in cooperation with the

U.S. FISH AND WILDLIFE SERVICE and

BUREAU OF RECLAMATION

This report is available only online 


\section{U.S. DEPARTMENT OF THE INTERIOR \\ GALE A. NORTON, Secretary}

U.S. GEOLOGICAL SURVEY

Charles G. Groat, Director

The use of firm, trade, and brand names in this report is for identification purposes only and does not constitute endorsement by the U.S. Geological Survey.

For additional information write to:

District Chief

U.S. Geological Survey

Water Resources Division

520 N. Park Avenue, Suite 221

Tucson, AZ 85719-5035
The URL for this report can be obtained from:

U.S. Geological Survey

Information Services

Box 25286

Federal Center

Denver, C0 80225-0046

Information about U.S. Geological Survey programs in Arizona is available online at http://az.water.usgs.gov. 


\section{CONTENTS}

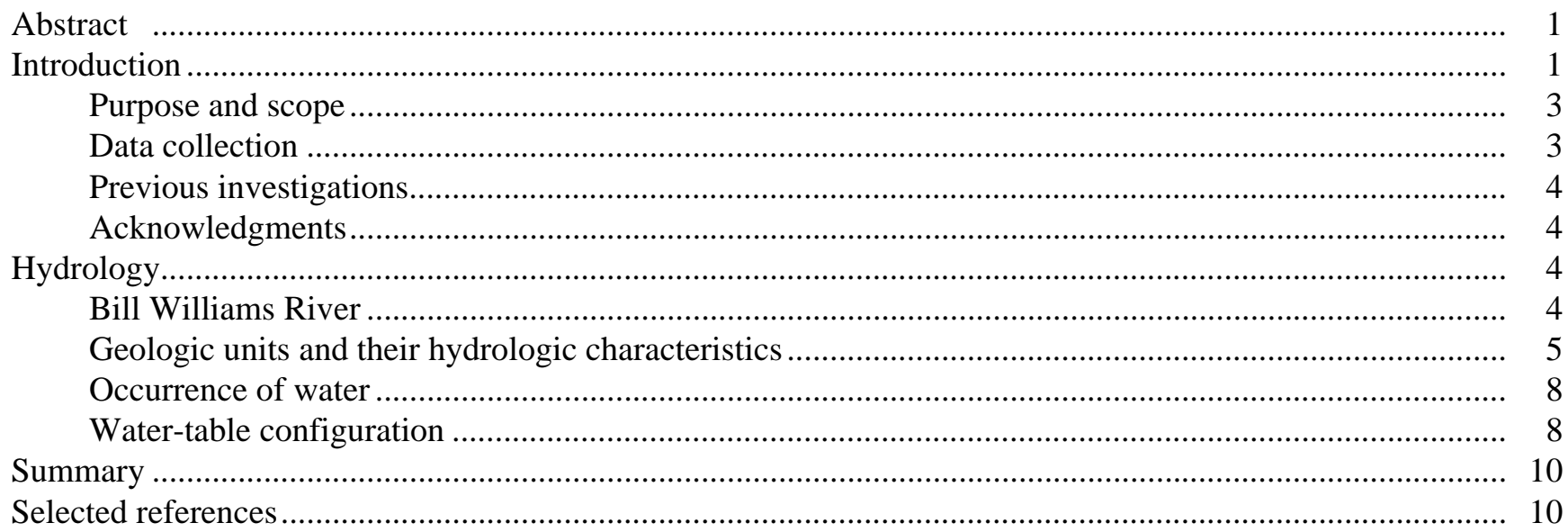

\section{PLATE}

1. Map showing river aquifer and elevation of the water table from Planet Valley to Lake Havasu along the Bill Williams River, Mohave and La Paz Counties, Arizona-2000

\section{FIGURES}

1. Map showing location of study area...

2-4. Graphs showing:

2. Annual flow in the Bill Williams River below Alamo Dam, 1940-2000, at Planet, 1929-45, and near Parker, 1989-2000

3. Annual loss in flow between the Bill Williams River below Alamo Dam and the Bill Williams River near Parker gaging stations, 1989-2000

4. Monthly flow in the Bill Williams River below Alamo Dam, 1990-2000 ...

\section{TABLES}

1. Streamflow-gaging stations on the Bill Williams River. 


\begin{tabular}{|c|c|c|}
\hline Multiply & By & To obtain \\
\hline inch & 2.54 & centimeter \\
\hline foot & 0.3048 & meter \\
\hline mile & 1.609 & kilometer \\
\hline square mile & 2.590 & square kilometer \\
\hline acre & 0.4047 & square hectometer \\
\hline acre-foot & 0.001233 & cubic hectometer \\
\hline cubic foot per second & 0.02832 & cubic meter per second \\
\hline gallon per minute & 0.06309 & liter per second \\
\hline
\end{tabular}

Vertical coordinate information is referenced to the National Geodetic Vertical Datum of 1929 (NGVD 29)—a geodetic datum derived from a general adjustment of the first-order level nets of both the United States and Canada, formerly called Sea Level Datum of 1929; horizontal coordinate information is referenced to the North American Datum of 1927 (NAD 27). Elevation, as used in this report, refers to distance above or below NGVD 29.

\section{WELL-NUMBERING AND NAMING SYSTEM}

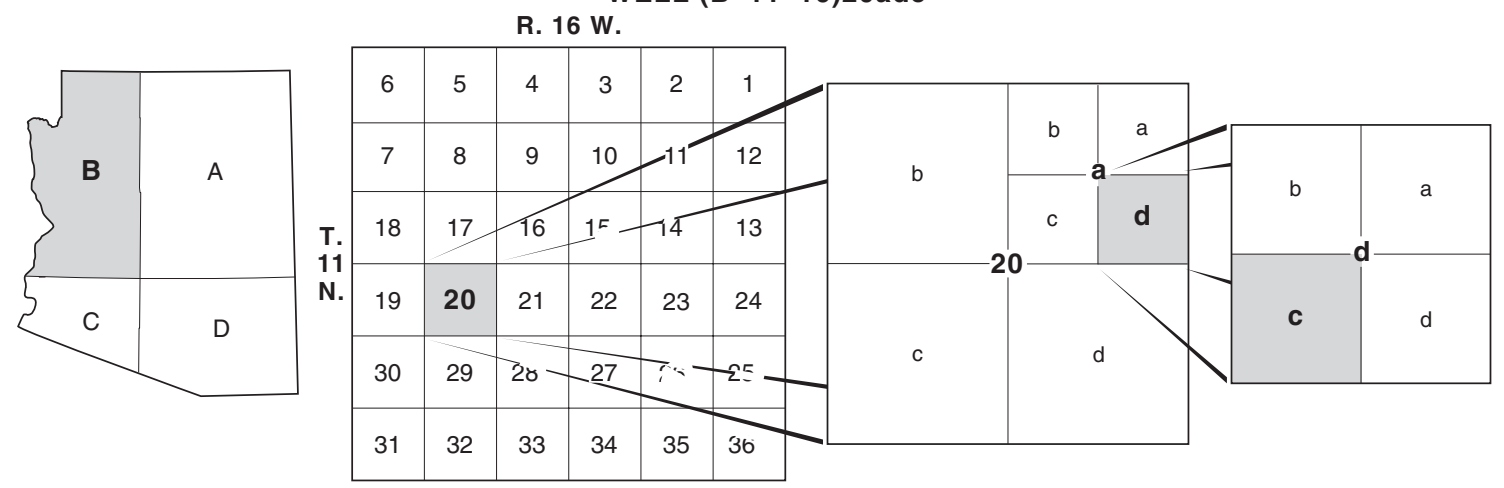

\section{Quadrant B, Township 11 North, Range 16 West, section 20,} quarter section a, quarter section d, quarter section $\mathrm{c}$

The well numbers used by the U.S. Geological Survey in Arizona are in accordance with the Bureau of Land Management's system of land subdivision. The land survey in Arizona is based on the Gila and Salt River meridian and base line, which divide the State into four quadrants and are designated by capital letters A, B, C, and D in a counterclockwise direction beginning in the northeast quarter. The first digit of a well number indicates the township, the second the range, and the third the section in which the well is situated. The lowercase letters $\mathrm{a}, \mathrm{b}, \mathrm{c}$, and $\mathrm{d}$ after the section number indicate the well location within the section. The first letter denotes a particular 160 -acre tract, the second the 40-acre tract, and the third the 10-acre tract. These letters also are assigned in a counterclockwise direction beginning in the northeast quarter. If the location is known within the 10 -acre tract, three lowercase letters are shown in the well number. Where more than one well is within a 10-acre tract, consecutive numbers beginning with 1 are added as suffixes. In the example shown, well number (B-11-16)20adc designates the well as being in the SW1/4, SE1/4, NE1/4, section 20, Township 11 North, and Range 16 West. 


\title{
Hydrologic Conditions in the Bill Williams River National Wildlife Refuge and Planet Valley, Arizona, 2000
}

\author{
By Richard P. Wilson and Sandra J. Owen-Joyce
}

\section{Abstract}

During a period of sustained base-flow conditions in the Bill Williams River below Alamo Dam in west central Arizona from March to July 2000, the channel of the river through Planet Valley was dry, and the water table sloped almost due west parallel to the main slope of the flood plain. Water from the river infiltrated into the channel bottom at the head of Planet Valley, moved downgradient in the subsurface, and reappeared in the channel about 0.3 mile downstream from the east boundary of the Bill Williams River National Wildlife Refuge. A river aquifer in hydraulic connection with the Bill Williams River was mapped from a point 6.3 miles upstream from Highway 95 to the upstream end of Planet Valley. Formations that make up the river aquifer in Planet Valley are younger alluvium, older alluviums, and fanglomerate. Total thickness of the river aquifer probably is less than 200 feet in the bedrock canyons to as much as 1,035 feet in Planet Valley. The purpose of this study was to investigate the current hydrologic conditions along the Bill Williams River, which included an inventory of wells within the river aquifer of the Colorado River and in Planet Valley, and to determine the configuration of the water table. A map shows the elevation and configuration of the water table from the east end of Planet Valley to the confluence of the Bill Williams River with Lake Havasu.

\section{INTRODUCTION}

The study area includes the flood plain and adjacent alluvial slopes within the Bill Williams River drainage basin that lie within the Bill Williams River National Wildlife Refuge (refuge) and Planet Ranch (fig. 1 and pl. 1). The basin is elongated east-west and is bounded by the Buckskin, Rawhide, and Bill Williams Mountains. The refuge includes riparian habitat along 9 miles of the river from its mouth at Lake Havasu to the downstream end of Planet Valley. The concept of a river aquifer best describes the hydrologic system along the Bill Williams River. A river aquifer consists of permeable partly saturated sediments and sedimentary rocks that are connected hydraulically to a river so that water can move between the river and the aquifer in response to withdrawal of water from the aquifer or differences in water-level elevations between the river and the aquifer. The subsurface limit of a river aquifer is the nearly impermeable bedrock of the bottom and sides of the basins that underlie the flood plain, alluvial slopes, and adjacent valleys (Wilson and Owen-Joyce, 1994).

Water in the Bill Williams River is connected hydraulically with and recharges the river aquifer, and water in this hydrologic system supports the riparian and wildlife habitat within the refuge, which is operated by the U.S. Fish and Wildlife Service. The U.S. Fish and Wildlife Service is concerned about receiving sufficient flow in the river for future maintenance of the habitat. Upstream from the refuge, water is pumped from wells for agricultural and domestic use at Planet Ranch, which is owned by the City of Scottsdale. This study was done in cooperation with the U.S. Fish and Wildlife Service and the Bureau of Reclamation. 


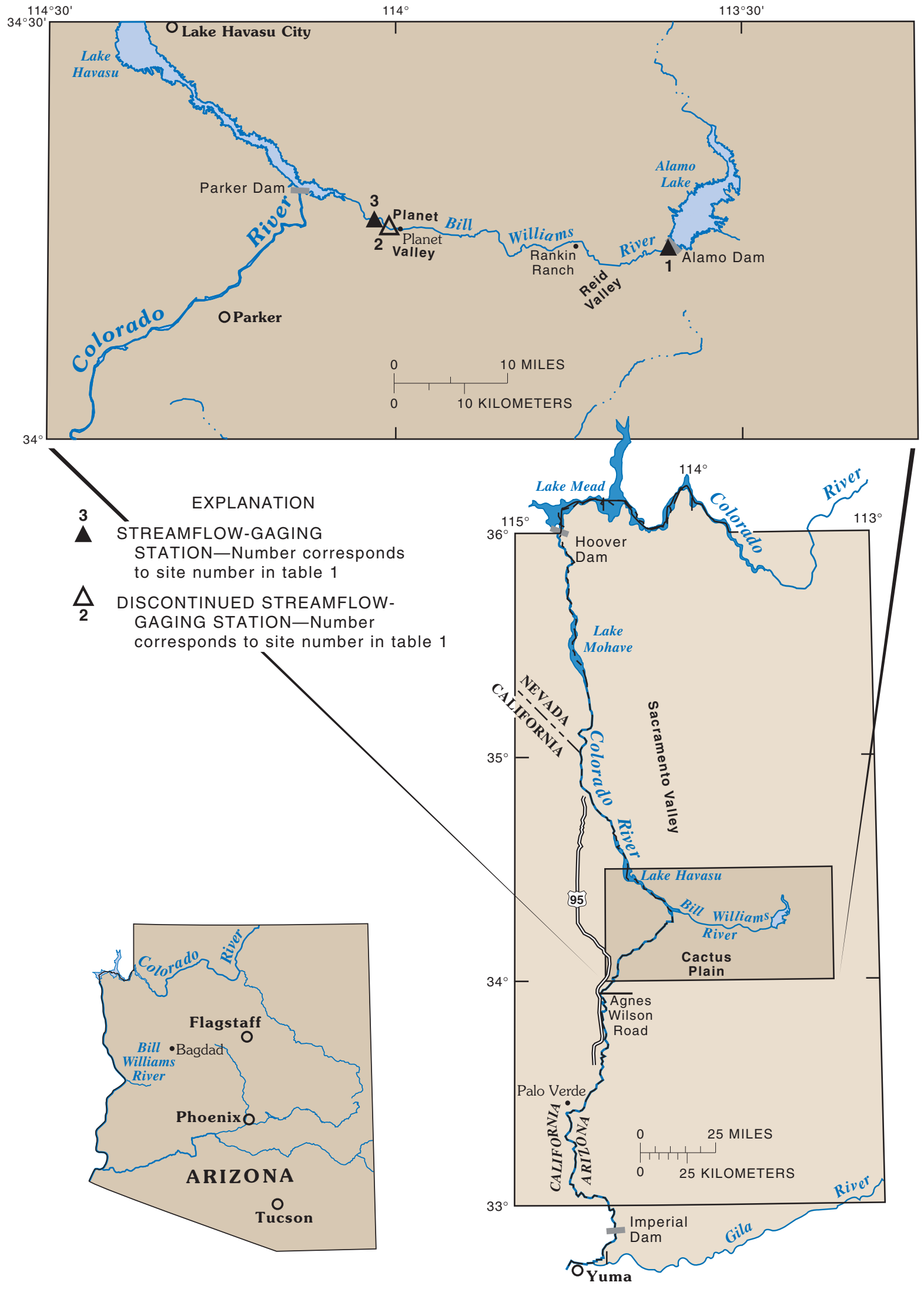

Figure 1. Location of study area. 


\section{Purpose and Scope}

The purpose of this study was to investigate the current (2000) hydrologic conditions along the Bill Williams River. The study included an inventory of wells within the river aquifer of the Colorado River and in Planet Valley, in which Global Positioning System (GPS) surveys were used to determine the precise location of the wells and the elevation of the land surface. These data were then used to determine the elevation and configuration of the water table. Most of the work was done in the downstream 15 miles of the river valley, which includes the Bill Williams River National Wildlife Refuge and Planet Valley. Access was not available to wells upstream of Planet Valley in Reid Valley and Rankin Ranch during the study, and little ground-water data exist for the reach.

This report documents the collection and interpretation of a current (2000) set of ground-water data and delineates the river aquifer along the reach of the Bill Williams River that includes Planet Valley and the refuge (fig. 1). The source and movement of water in the river aquifer and the sediments, the sedimentary rocks that transmit and store the water, and the generalized surface extent of the sediments and sedimentary rocks that form the river aquifer are described in the report. A map is included (pl. 1) that shows the elevation and configuration of the water table.

\section{Data Collection}

The U.S. Geological Survey (USGS) collected hydrologic data for the study from March to July 2000. The river aquifer associated with the Bill Williams River was defined and delineated from previous geologic and hydrologic studies, field reconnaissance, well records documented by Turner (1962), and drillers' logs and pump-test data in the files of the Arizona Department of Water Resources. Streamflow discharges were obtained from USGS streamflowgaging stations. Annual data in this report are based on the calendar year. An inventory was made of 61 wells, mainly on the flood plain, to collect the hydrologic data required to delineate the water table. Static-water levels were measured by using steel tapes and calibrated electric-well sounders in those wells where owners permitted access and the measuring instruments could be inserted into the well. Static-water levels were combined with the GPS measuring-point data to determine static water-level elevations. Wells locations are described in accordance with the well-numbering system used in Arizona. Orthometric heights of measuring points, which approximate elevations that are determined by use of spirit levels, were determined by GPS surveys during hydrologic data collection at irrigation wells, observation wells, streamflow-gaging stations, and selected points along the water surface of the Bill Williams River. All well data are stored in the Arizona National Water Information System (NWIS) database in Tucson, Arizona. Site information and water-level data are available from the NWISWeb database at http://waterdata.usgs.gov/nwis/

GPS geodetic receivers were used in differential mode to survey the latitude, longitude, and elevation of wells (Remondi, 1985). During March and April 2000, USGS, U.S. Fish and Wildlife Service, and Bureau of Land Management personnel made GPS surveys of National Geodetic Survey (NGS) GPS and vertical control points near and along the Bill Williams River from Alamo Dam to the mouth at Lake Havasu. Four GPS control points at Lake Havasu City airport, Parker airport, near Bagdad, Arizona, and the intersection of Agnes Wilson Road and Highway 95 in California were tied to first-order vertical control bench marks near Planet Ranch and Alamo Dam. Elevation values were previously determined for the vertical control marks by NGS using spirit levels, but none of them had been tied to the GPS control points. A temporary GPS base station mark was set at Planet Ranch for use in later surveys. Five GPS receivers were used in static mode over 2 days to determine vectors (base lines) between the GPS control points and the vertical control marks. Precise ephemerides were used during differential data processing when available.

The positions of the control points were adjusted by holding the horizontal coordinates of the four GPS points and the orthometric heights of the vertical control points fixed. The adjusted values of ellipsoid height ranged from -0.053 to +0.147 meter from NGS published values. Horizontal coordinates obtained by using GPS were converted from the World Geodetic System of 1984 (WGS 84) to the North American Datum of 1983 (NAD 83); orthometric heights were referenced to the North American Vertical Datum of 1988 (NAVD 88). Geoid separations were obtained from geoid model GEOID 96. All land-surface or water-surface elevations in this report are referenced to the National Geodetic Vertical Datum of 1929 
(NGVD 29); horizontal coordinates are referenced to the North American Datum of 1927 (NAD 27).

Positions and elevations of points obtained by use of the GPS were converted to these datums by the program Corpscon (U.S. Army Topographic Engineering Center, 1997) to facilitate comparison with previous studies.

\section{Previous Investigations}

The earliest water-resources investigation of the area along the Bill Williams River was done by Wolcott and others (1956). The first systematic study of the water resources and ground-water hydrology was done by Turner (1962). The Turner report provides records of well and pump tests, chemical quality of ground water, base flow in the river, and geologic data that includes estimates of thickness and general descriptions of permeable sediments beneath and adjacent to the flood plain at Planet Ranch that were determined from interpretation of data from surfacegeophysical soundings. Basic data collected in 1980 were compiled as maps showing ground-water conditions in the Bill Williams area (Sanger and Littin, 1981). Geology of the Castaneda Hills SW and Centennial Wash quadrangles was mapped, and geologic units were defined and described (Lucchita and Suneson, $1994 \mathrm{a}, \mathrm{b}$ ). The Bill Williams River, a tributary to the Colorado River, was included in studies of the lower Colorado River (Metzger and others, 1973; Owen-Joyce, 1987; Wilson and Owen-Joyce, 1994; Owen-Joyce and Raymond, 1996). Other studies included hydrology and riparian restoration (Harshman and Maddock, 1993), hydrologic and geomorphic characteristics (House and others, 1999), and streamaquifer interactions using a coupled model (Vionnet and others, 1997).

\section{Acknowledgments}

Special appreciation is extended to the landowners who provided well records and access to their property. Surveys were made and hydrologic data were collected with the assistance of Andrew Hautzinger, Dale R. Fox, Richard Gilbert, Kathleen Blair, and Tim Miller, U.S. Fish and Wildlife Service; and Cory Bodham, Bureau of Land Management. The City of Scottsdale, Arizona, provided access to Planet Ranch, hydrologic data, well records, and the assistance of its employees Larry Byers, Planet Ranch Manager, and Pat Stafford.

\section{HYDROLOGY}

A river aquifer in hydraulic connection with the Colorado River extends about 6.3 miles upstream from Lake Havasu along the Bill Williams River and was delineated and described by Wilson and Owen-Joyce (1994). Most of the refuge lies within the river aquifer along the Colorado River. The permeable sediments that make up the river aquifer along the Colorado River are continuous in the subsurface with sediments that form a river aquifer along the Bill Williams River upstream from that point. Water in the upstream river aquifer is connected hydraulically to surface flow in the Bill Williams River and the river aquifer extends upstream to Alamo Dam, but was mapped only to the east end of Planet Valley in this study (pl. 1). The following sections describe the principal components of the hydrologic system along the Bill Williams River: flow in the river, the geologic units and their hydrologic characteristics, the occurrence of water, and the configuration of the water table in Planet Valley.

\section{Bill Williams River}

The Bill Williams River drains about 5,400 square miles and is the largest river in northwestern Arizona and the largest tributary to the Colorado River between Hoover and Imperial Dams (fig. 1). Flow in the Bill Williams River has been regulated since 1969 by Alamo Dam, about 36 miles upstream from Lake Havasu, and releases of water are controlled by the U.S. Army Corps of Engineers. Water stored in Alamo Lake is released to meet downstream water requirements and to make storage available for flood control. The maximum controlled release from the dam is 7,000 cubic feet per second. The peak discharge before the dam was constructed was 200,000 cubic feet per second in February 1891 (Patterson and Somers, 1966, p. 48). Peak discharge after the dam was constructed was 6,980 cubic feet per second in March 1993 (Tadayon and others, 2000, p. 112). Base flow of the river is maintained by low-flow releases through Alamo Dam of about 9 to 50 cubic feet per second during most of each year. The Bill Williams River flows into Lake Havasu (pl. 1) just upstream from Parker Dam. 
Flow in the Bill Williams River is measured below Alamo Dam (site 1, fig. 1; table 1) at a streamflowgaging station established by the USGS to monitor releases from Alamo Dam for the U.S. Army Corps of Engineers. The Corps of Engineers uses the streamflow data to operate the dam for flood control, for storage, and to maintain a base flow of 10 cubic feet per second to meet a downstream water right. Annual flow downstream from the Alamo Dam ranged from 1,270 to 701,500 acre-feet (fig. 2) and averaged 85,500 acre-feet between 1940 and 1999, and averaged 108,600 acre-feet between 1989 and 1999. Flow also is measured at a streamflow-gaging station near Parker, about 5.3 miles upstream from Lake Havasu (site 3, fig. 1; table 1) where the average annual flow between 1989 and 1999 (fig. 2) was 87,300 acre-feet. During the time both gaging stations have been in operation, the reach between the stations has been a losing reach (fig. 3).

Below Alamo Dam, tributary inflow to the Bill Williams River from about 700 square miles is unmeasured. Between the streamflow-gaging station below Alamo Dam and the mouth, average annual runoff was estimated to be 4,000 acre-feet (Metzger and Loeltz, 1973, p. 35); average annual ground-water discharge to the river was estimated to be 4,000 acrefeet (Metzger and Loeltz, 1973, p. 36).

Table 1. Streamflow-gaging stations on the Bill Williams River

\begin{tabular}{ccl}
\hline $\begin{array}{c}\text { Site } \\
\text { number }\end{array}$ & $\begin{array}{c}\text { Station } \\
\text { number }^{2}\end{array}$ & \multicolumn{1}{c}{ Station name } \\
\hline 1 & 09426000 & Bill Williams River below Alamo Dam \\
2 & 09426500 & Bill Williams River at Planet ${ }^{3}$ \\
3 & 09426620 & Bill Williams River near Parker \\
\hline
\end{tabular}

\section{${ }^{1}$ Locations plotted on figure 1 .}

${ }^{2}$ Assigned by the U.S. Geological Survey.

${ }^{3}$ U.S. Geological Survey discontinued site October 1946.

\section{Geologic Units and their Hydrologic Characteristics}

Geologic units that make up the river aquifer associated with the Colorado River occur along the Bill Williams River from the mouth to a point 6.3 miles upstream from Highway 95 and are younger alluvium, older alluviums, Bouse Formation, and fanglomerate (Wilson and Owen-Joyce, 1994, pl. 12). These units partially fill structural basins and canyons that are underlain and rimmed with nearly impermeable bedrock.
A similar river aquifer is in hydraulic connection with the Bill Williams River from that point 6.3 miles upstream from Highway 95 to Alamo Dam, a distance of 30 miles, although for this study the river aquifer was only mapped to the upstream end of Planet Valley (pl. 1). This river aquifer ranges in width from about 6 miles in Planet Valley to 400 feet in the canyon downstream from Planet Valley and is 100 feet wide in the canyon below Alamo Dam. Geologic units that make up the river aquifer in this reach are continuous in the subsurface with those along the Colorado River, but the sources of the sediment are local and distinct to the Bill Williams drainage basin. Terminology used to describe the units along the Colorado River is used for the geologic units of the river aquifer along the Bill Williams River because the units are similar in origin and age. The units are the younger alluvium, older alluviums, and fanglomerate. The Bouse Formation was not recognized in the lithologic and geophysical logs of well (B-11-16)20adc, which penetrated the full thickness of older alluviums and fanglomerate and bottomed in bedrock (Lease, 1981). Although complexly fractured and faulted, the bedrock transmits and stores insignificant quantities of water compared to the river aquifer and limits hydraulic connection between the river aquifer along the Bill Williams River and aquifers in the adjacent alluvial basins of Sacramento Valley and the Cactus Plain.

Total saturated thickness of the river aquifer along the Bill Williams River ranges from less than 200 feet in the bedrock canyons to as much as 1,380 feet in Planet Valley at well (B-11-16)20adc (see cross section on pl. 1). Well (B-11-16)20adc penetrates the full thickness of the river aquifer above and north of the flood plain where the younger alluvium is absent. Interpreted lithologic and geophysical logs (Lease, 1981) indicate the well penetrates 785 feet of older alluviums and 845 feet of fanglomerate. The fanglomerate interval consists of 147 feet of fanglomerate overlying 318 feet of volcanic rocks, flows and tuff that are underlain by 380 feet of fanglomerate. Bedrock penetrated by well (B-11-16)20adc consists of 380 feet of hematite-matrix conglomerate and sandstone, 100 feet of metasediments, and at least 441 feet of chlorite schist. An interpreted driller's log of well (B-11-16)16bba indicates the well penetrates 300 feet of undifferentiated older alluviums, 50 feet of fanglomerate, and 150 feet of volcanic rocks. The older alluviums and fanglomerate are above the water table; 138 feet of the volcanic rocks are saturated and open to the well.

Younger alluvium is highly permeable and consists of regionally derived rounded boulders, cobbles, gravel, and sand transported by the Bill Williams River. 


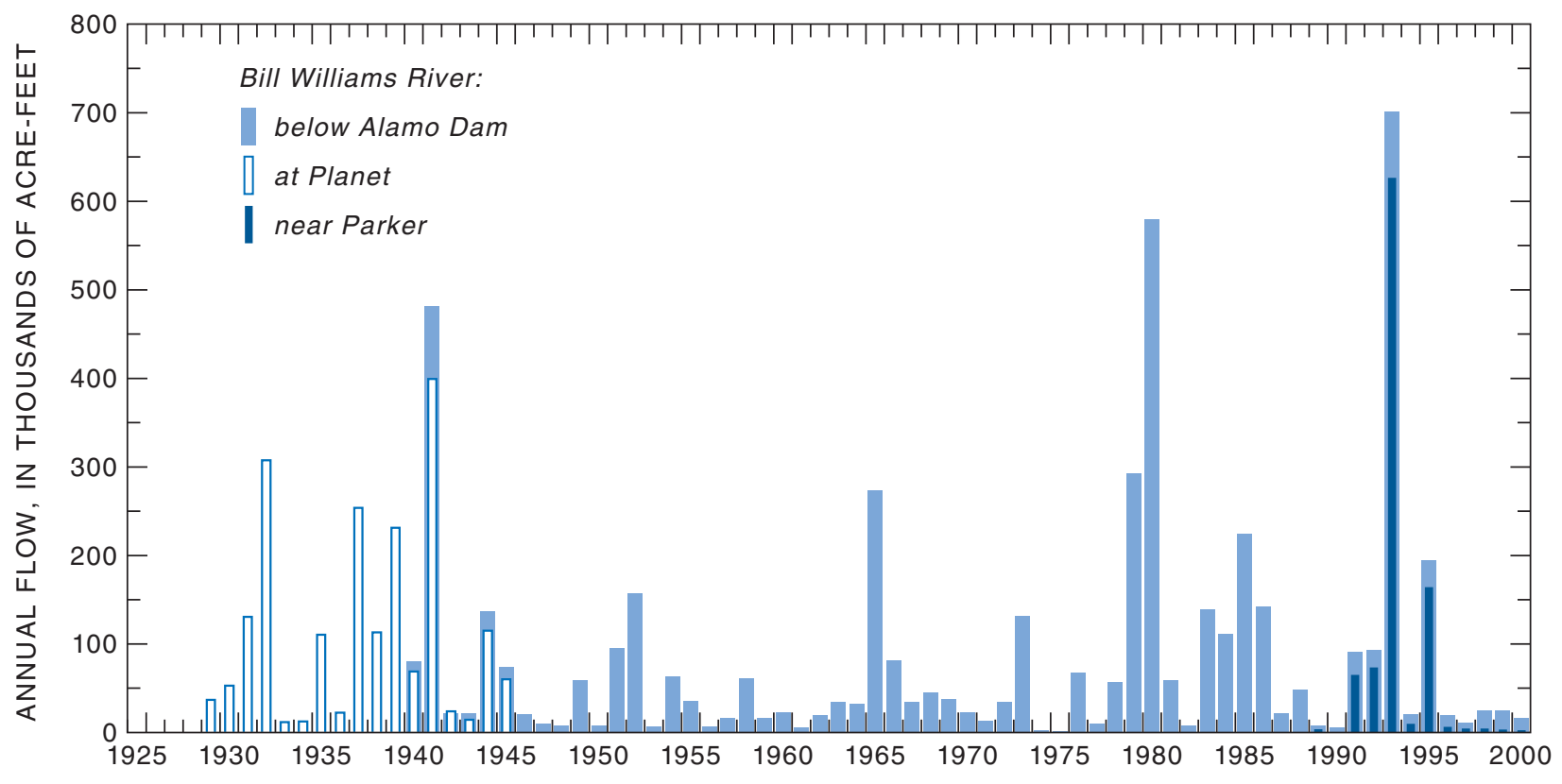

Figure 2. Annual flow in the Bill Williams River below Alamo Dam, 1940-2000, at Planet, 1929-45, and near Parker, 1989-2000.

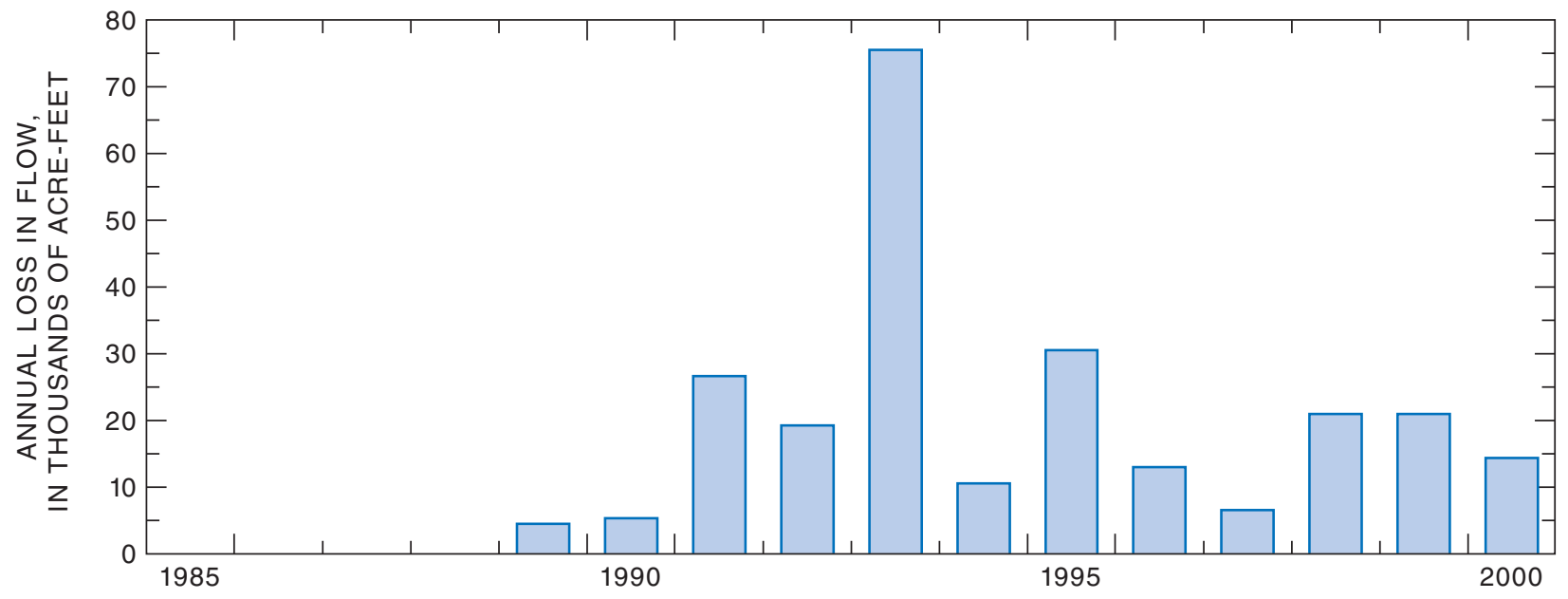

Figure 3. Annual loss in flow between the Bill Williams River below Alamo Dam and the Bill Williams River near Parker gaging stations, 1989-2000. 
The uppermost few feet are described as "sand and gravel of present day channels" (Lucchitta and Suneson, 1994a). Silt and clay are largely absent. In the flood plains of larger washes draining to the river, younger alluvium is locally derived and was called "alluvium of active channels" (Lucchitta and Suneson, 1994a). In Planet Valley, the flood plain is underlain by younger alluvium that forms a body 6.2 miles long and 0.3 to 1.2 miles wide. Well-log data from Planet Ranch wells and geophysical data from a previous study (Turner, 1962) indicate the younger alluvium is about 140 feet thick. Saturated thickness is from 100 to about 135 feet. Flood plains of Castaneda Wash and four unnamed washes immediately to the east that drain to the Bill Williams River are underlain by tens to perhaps more than 100 feet of locally derived younger alluvium near their mouths at the edge of the flood plain. That material probably is saturated near the point where the washes meet the edge of the flood plain.

In the Yuma, Palo Verde, and Parker areas, Pleistocene (?) terraces of Colorado River sediments are about 70 to 80 feet above the modern flood plain and were deposited by the river at a time when sea level was at maximum stage and the Colorado River was graded to sea level at about its present slope (Metzger and others, 1973, p. 33; Olmsted and others, 1973, p. 27). At that same time, the channel of the Bill Williams River and its associated alluvial slopes were graded to the Colorado River. In Planet Valley, the Pleistocene (?) flood plain was about 90 feet above the modern flood plain. Projected surface slopes of the older alluviums north of the flood plain and a terrace in section 25, T. 11 N., R. $16 \mathrm{~W}$. both indicate the river flowed about 90 feet higher than the modern flood plain. When the Colorado River cut down to its maximum depth of about 120 feet below its modern flood plain during the late Pleistocene, the Bill Williams River also would have cut down into its gravels, older alluviums, or bedrock and graded to the Colorado River. In Planet Valley, that surface of maximum downcutting probably is about 140 feet below the modern flood plain. It likely is relatively flat in cross section because there was a period of neither cutting or filling when the river meandered back and forth and produced a relatively smooth flood plain. The younger alluvium is deposited on that surface and is the last unit deposited by the Bill Williams River along its flood plain in response to the rising level of younger alluvium along the flood plain of the Colorado River during late Pleistocene and Holocene deposition.

Younger alluvium is highly permeable; all successful irrigation wells on Planet Ranch appear to be completed in that unit. These wells yield as much as 4,000 gallons per minute. The specific capacities of
10 irrigation wells along the river range from 64 to 250 gallons per minute per foot of drawdown. The Bill Williams River channel is cut into younger alluvium, and recharge from and discharge to the river moves through this unit.

Older alluviums of Planet Valley are equivalent to the older alluviums along the Colorado River (Metzger and others, 1973) because in both areas the unit is deposited on fanglomerate. In well (B-11-16)20adc the lithology of the upper and lower parts of the older alluviums are different. The upper part consists of gravel and sand of local origin that were eroded from high areas on each side of the river. The upper part underlies the younger alluvium along the north part of the flood plain in Planet Valley. The lower part consists of gravel and sand of regional origin and contains subrounded to well-rounded sand of unknown origin. The lower part was deposited on the volcanic and sedimentary rocks of the fanglomerate. The older alluviums could yield 100 to 1,000 gallons per minute to wells where several hundred feet are saturated.

Fanglomerate consists of weakly to moderately consolidated boulders, gravel, sand, silt, and clay of local origin that are interbedded with gently dipping tuffs and basalt flows (Metzger and others, 1973). North of the flood plain, the volcanic rocks in the subsurface are saturated. In much of the area, the volcanic rocks are above the water table and dry. The volcanic rocks of the fanglomerate are poorly permeable and can yield a few hundred gallons per minute to wells where several hundred feet of the volcanic rocks are saturated. Well (B-11-16)16bba is open to 138 feet of saturated volcanic rocks and was test pumped at 110 gallons per minute with 80 feet of drawdown. The sedimentary units of the fanglomerate probably will yield a few tens to a few hundreds of gallons per minute to wells.

Bedrock includes a variety of crystalline metamorphic and igneous intrusive rocks and volcanic, sedimentary, and metasedimentary rocks that range in age from Tertiary to Precambrian. Geologic structure of the Bill Williams, Buckskin, and Rawhide

Mountains is complex, and the several formations that make up the bedrock are faulted and tilted. Formations that make up the bedrock are consolidated, dense, and poorly permeable to impermeable. Intrusive igneous and metamorphic formations are nearly impermeable. Cretaceous (?) and Tertiary conglomerate, sandstone, and mudstone are cemented and consolidated, and store and yield little water. 


\section{Occurrence of Water}

In Planet Valley, several continental sedimentary formations-younger alluvium, older alluviums, and fanglomerate - beneath and adjacent to the flood plain are permeable and form the river aquifer. Recharge to the river aquifer is available from the Bill Williams River, precipitation, and inflow from adjacent tributary valleys. The main control of water-table elevation and slope in the river aquifer is recharge from and discharge to the main channel of the Bill Williams River. The channel conveys most of the surface water through the system. Water levels beneath the flood plain rise and fall in response to changes in stage and discharge along the river. When water moves into the aquifer through the bed and banks of the channel during high flows, ground-water levels rise; when water drains back into the channel during low flows, ground-water levels decline. Peak discharges are rapidly attenuated and base flows are prolonged by the large quantity of aquifer storage along the river. The quantity of surface flow entering the refuge is substantially influenced by movement of water back and forth between the river channel and the river aquifer and by the quantity of water lost to evaporation, transpiration, and agricultural usage between the refuge and Alamo Dam.

The volume of river aquifer is substantial in three reaches upstream from the refuge along about 11 of the 25 miles to Alamo Dam; storage is relatively small where the river flows through narrow bedrock canyons. Aquifer storage in Planet Valley is much greater than in Reid Valley and at Rankin Ranch and is a major control of base flow into the refuge.

Movement of water between the river channel and the uppermost layer of the river aquifer, younger alluvium, dominates the base-flow hydrology of Planet Valley and the refuge. Base flows of less than about 50 cubic feet per second infiltrate into the channel bottom about 6 miles upstream from the east refuge boundary and move downvalley in the younger alluvium. The subsurface flow probably is concentrated along the center and southwestern part of the valley as indicated by high specific capacities of wells in those areas. Surface flow reappears in the channel about 0.3 mile downstream from the refuge boundary near the west end of Planet Valley and is present throughout much of the refuge. In several short reaches, surface base flow infiltrates into the channel bottom and moves downstream as subflow. During high-flow periods, flow is continuous from Alamo Dam to and through the refuge.

The largest quantity of aquifer storage is in Planet Valley. Under current conditions (2000), the amount of aquifer storage in Planet Valley that can affect base flow in the river is the volume of pore space in the uppermost part of the river aquifer between the highest and lowest positions of the water table. The water table is highest during periods of sustained high flow in the river, such as during the flood flows of 1993 and 1995. The lowest position occurs during periods of sustained minimum releases through Alamo Dam and no surface flow in Planet Valley. If the specific yield of the younger alluvium is assumed to be about 20 percent and changes in water levels are about 20 feet, about 15,000 acre-feet of storage is available in the younger alluvium. On the basis of 8 percent specific yield, about 16,000 acre-feet more storage is available in the older alluviums of the river aquifer, but the lower hydraulic conductivity of this unit prevents rapid movement of water to and from the younger alluvium.

\section{Water-Table Configuration}

Static water-level elevations at 23 wells and 1 water-surface elevation along the river were used to estimate the slope and shape of the water table in Planet Valley. Most of the wells inventoried are irrigation wells associated with Planet Ranch and distributed across the flood plain. The water table slopes almost due west parallel to the main slope of the flood plain. The hydraulic gradient is about 23 feet per mile ( 0.0044 foot/foot) where flow is constricted in the upstream end of the valley, 10 feet per mile

( 0.0019 foot/foot) in the center of the valley where the cross-sectional area of the younger alluvium is greatest, and 21 feet per mile ( 0.004 foot/foot) in the

downstream end of the valley where flow converges to enter the canyon in the refuge.

Static water-level elevations at 27 wells were used to estimate the slope of the water table along the reach of the river downstream from Planet Valley. Most of the wells inventoried are observation wells installed near the banks of the river. Contours were not used to define the configuration of the water table downstream from Planet Valley because of the narrow flood plain, lack of distribution of wells across the flood plain in this reach, the lack of elevation data for the river surface, dense vegetation, and many beaver ponds. Data from individual wells indicate that the water table continues to slope almost due west, parallel to the main slope of 
the flood plain where the river is constricted in a canyon between Planet Valley and the river aquifer of the Colorado River and where the hydraulic gradient is about 18 feet per mile ( 0.0034 foot/foot). The water table slopes northwest, parallel to the main slope of the flood plain in the river aquifer of the Colorado River where the hydraulic gradient is about 19 feet per mile ( 0.0036 foot/foot). Within about 2 miles of Lake Havasu, no wells exist on the flood plain, which is at times in backwater from the lake.

Reconnaissance showed that dense phreatophytes were transpiring water in the reach between the gaging station below Alamo Dam and the confluence with the Colorado River. Surface water was not diverted for irrigation along the Bill Williams River in Planet Valley during the study period in 2000. The predominant use of water in Planet Valley and the refuge was transpiration by riparian vegetation on the flood plain. Ground water was pumped from an irrigation well to irrigate 27 acres of alfalfa and about 2 acres of lawn grass at Planet Ranch.

At the time of this study, ground-water flow was dominated by recharge from and discharge to the river. Flow in the river channel and water-level elevations in the river aquifer were representative of sustained baseflow conditions (fig. 4). The channel of the river through Planet Valley was dry, which is reflected in the contour lines being perpendicular to the stream channel. Water infiltrated into the channel bottom at the head of the valley, moved downgradient in the subsurface, and reappeared in the channel about 0.3 mile downstream from the east refuge boundary.
Discharges were a few cubic feet per second through the refuge to the mouth; short reaches of the channel were dry. During data collection in March through July 2000, monthly mean discharges at Alamo Dam ranged from 22.1 to 23.0 cubic feet per second; discharges during the previous 3 months ranged from 23.0 to 24.3 cubic feet per second. The last flow above typical base flows occurred April 7-9, 1998, with a maximum daily discharge of 639 cubic feet per second. The last major flow that covered the channel bottom and much of the flood plain was in February and March 1995.

Minimal recharge from older alluviums north of the flood plain appeared to be occurring during 2000. Measurements in two wells in Castaneda Wash, (B-11-16)29aaa and (B-11-16)29dac, indicated the gradient was near zero in a north-south direction; data from additional wells are required to accurately delineate flow direction north of the flood plain. Well (B-11-16)16bba is about 3 miles north of the edge of the younger alluvium and is completed in volcanic rocks within the fanglomerate and the older alluviums above are dry. The static water-level elevation in well (B-11-16)16bba was about 11 feet above that in the younger alluvium, which indicates that hydraulic connection between the units is poor. Small amounts of recharge to the river aquifer will occur when heavy rainfall causes flooding in the five large washes that drain the area to the north of the flood plain. In most years, rainfall is too little and infrequent to produce significant recharge.

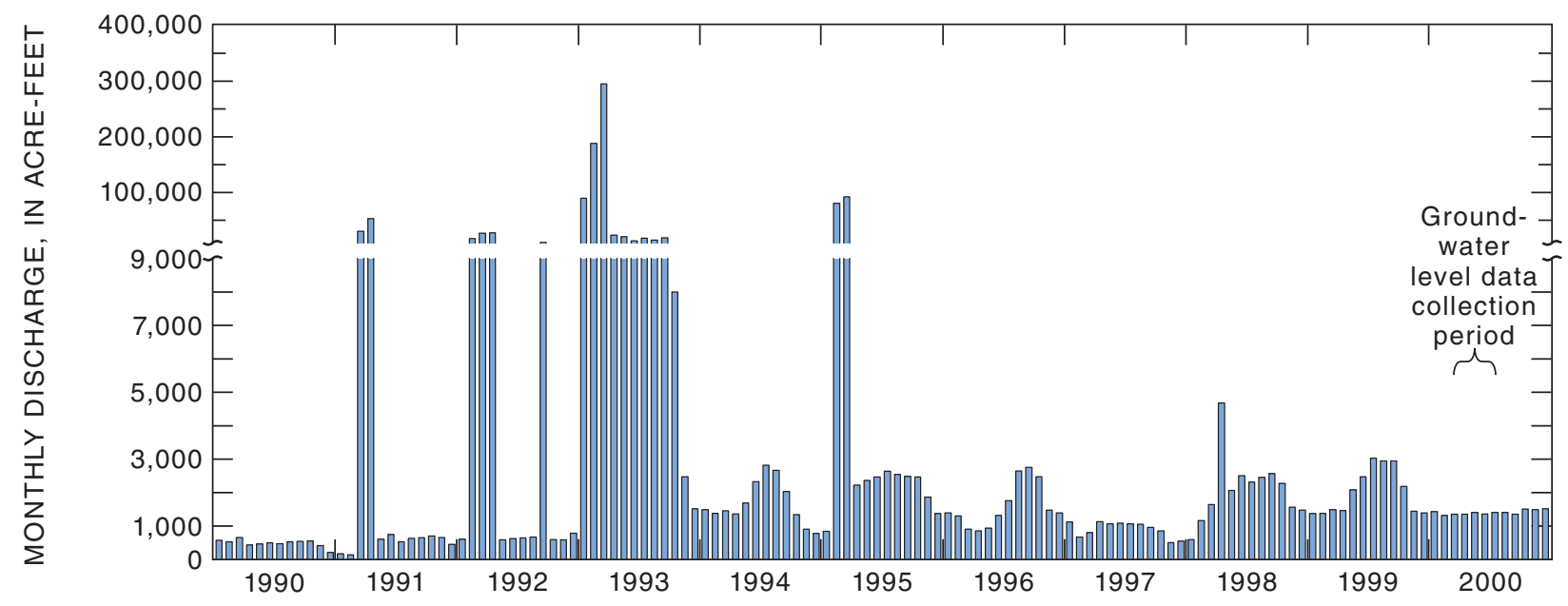

Figure 4. Monthly flow in the Bill Williams River below Alamo Dam, 1990-2000. 


\section{SUMMARY}

A river aquifer in hydraulic connection with the Bill Williams River was mapped from a point 6.3 miles upstream from Highway 95 to the upstream end of Planet Valley although it extends upstream to Alamo Dam. It varies in width from about 6 miles in Planet Valley to 400 feet in the canyon downstream from Planet Valley and to 100 feet in the canyon below Alamo Dam. Formations that make up the river aquifer in this reach are younger alluvium, older alluviums, and fanglomerate. Total thickness of the river aquifer probably is less than 200 feet in the bedrock canyons and as much as 1,035 feet in Planet Valley where the younger alluvium is about 140 feet thick. Saturated thickness in the younger alluvium is from 100 to about 135 feet.

Data were collected from March to July 2000 during a period of sustained base-flow conditions in the Bill Williams River below Alamo Dam. The channel of the river through Planet Valley was dry, and the water table sloped almost due west parallel to the main slope of the flood plain. Water from the river infiltrated into the channel bottom at the head of the Planet Valley, moved downgradient in the subsurface, and reappeared in the channel about 0.3 mile downstream from the east boundary of the Bill Williams River National Wildlife Refuge.

\section{SELECTED REFERENCES}

Harshman, C.A., and Maddock, Thomas, III, 1993, The hydrology and riparian restoration of the Bill Williams River basin near Parker, Arizona: University of Arizona duplicated report HWR no. 93-040, v.p.

House, P.K., Wood, M.L., and Pearthree, P.A., 1999, Hydrologic and geomorphic characteristics of the Bill Williams River, Arizona: Arizona Geological Survey Open-File Report 99-4, 46 p.

Lease, L.W., 1981, Summary geologic report on drilling in western Prescott and Williams quadrangles, Mohave, Yavapai, and Yuma Counties, Arizona: Grand Junction, Colorado, Bendix Field Engineering Corporation Grand Junction Operations, unpublished report GJBX-293(81), p. 65-66, borehole geophysical log 0-2457 feet, 1 graph.

Lucchitta, Ivo, and Suneson, Neil, 1994a, Geologic map of the Castaneda Hills SW quadrangle, Mohave and La Paz Counties, Arizona: U.S. Geological Survey Geologic Quadrangle Map GQ-1718, 1 sheet, scale 1:24,000, explanatory pamphlet $7 \mathrm{p}$. 1994b, Geologic map of the Centennial Wash quadrangle, Mohave and La Paz Counties, Arizona: U.S. Geological Survey Geologic Quadrangle Map GQ-1719, 1 sheet, scale 1:24,000.

Metzger, D.G., 1965, A Miocene(?) aquifer in the ParkerBlythe-Cibola area Arizona and California: U.S. Geological Survey Professional Paper 525-C, p. C203-C205.

1968, The Bouse Formation (Pliocene) of the ParkerBlythe-Cibola area, Arizona and California: U.S. Geological Survey Professional Paper 600-D, p. D126-D136.

Metzger, D.G., Loeltz, O.J., and Irelan, Burdge, 1973, Geohydrology of the Parker-Blythe-Cibola area, Arizona and California: U.S. Geological Survey Professional Paper 486-G, 130 p.

Olmsted, F.H., Loeltz, O.J., and Irelan, Burdge, 1973, Geohydrology of the Yuma Area, Arizona and California: U.S. Geological Survey Professional Paper 486-H, $227 \mathrm{p}$.

Owen-Joyce, S.J., 1987, Estimates of average annual tributary inflow to the lower Colorado River, Hoover Dam to Mexico: U.S. Geological Survey WaterResources Investigations Report 87-4078, 1 sheet.

Owen-Joyce, S.J., and Raymond, L.H., 1996, An accounting system for water and consumptive use along the Colorado River, Hoover Dam to Mexico: U.S. Geological Survey Water-Supply Paper 2407, 94 p.

Owen-Joyce, S.J., and Wilson, R.P., 1994, Accounting for consumptive use of lower Colorado River water in Arizona, California, Nevada, and Utah: U.S. Geological Survey Fact Sheet 94-074, 2 p.

Patterson, J.L., and Somers, W.P., 1966, Magnitude and frequency of floods in the United States, Part 9, Colorado River Basin: U.S. Geological Survey WaterSupply Paper 1683, 475 p.

Remondi, B.W., 1985, Global Positioning System carrier phase-Description and use: Rockville, Maryland, National Oceanic and Atmospheric Administration Technical Memorandum NOS NGS-42, 21 p.

Sanger, H.W., and Littin, G.L., 1981, Maps showing groundwater conditions in the Bill Williams area, Mohave, Yavapai, and Yuma Counties, Arizona-1980: U.S. Geological Survey Water-Resources Investigations Report 82-87, 2 sheets.

Spencer, J.E., and Reynolds, S.J., editors, 1989, Geology and mineral resources of the Buckskin and Rawhide Mountains, west-central Arizona: Arizona Geological Survey Bulletin 198, 3 plates, 279 p.

Tayadon, Saeid, Duet, N.R., Fisk, G.G., McCormack, H.F., Partin, C.K., Pope, G.L., and Rigas, P.D., 2000, Water resources data Arizona water year 1999: U.S. Geological Survey Water-Data Report AZ-99-1, 370 p. 
Turner, S.F., 1962, Water resources of the Planet Ranch on Bill Williams River, Mohave and Yuma Counties, Arizona: Arizona Ranch and Metals Company duplicated report, $47 \mathrm{p}$.

U.S. Army Topographic Engineering Center, 1997, Corpscon version 5.x, Technical Documentation and Operating Instructions, accessed August 1999, at URL http://crunch.tec.army.mil/software/corpscon/ corpscon.html\#files.

Vionnet, L.B., Maddock, Thomas, III, Goodrich, D.G., 1997, Investigation of stream-aquifer interactions using a coupled surface-water and ground-water flow model: University of Arizona duplicated report HWR no. 97-020, v.p.
Wilson, R.P., and Owen-Joyce, S.J., 1993, Determining the source of water pumped from wells along the lower Colorado River: U.S. Geological Survey Open-File Report 93-405, 2 p.

1994, Method to identify wells that yield water that will be replaced by Colorado River water in Arizona, California, Nevada, and Utah: U.S. Geological Survey Water-Resources Investigations Report 94-4005, 19 plates, $36 \mathrm{p}$.

Wolcott, H.N., Skibitzke, H.E., and Halpenny, L.C., 1956, Water resources of Bill Williams River Valley near Alamo, Arizona: U.S. Geological Survey Water-Supply Paper 1360-D, p. 291-319. 

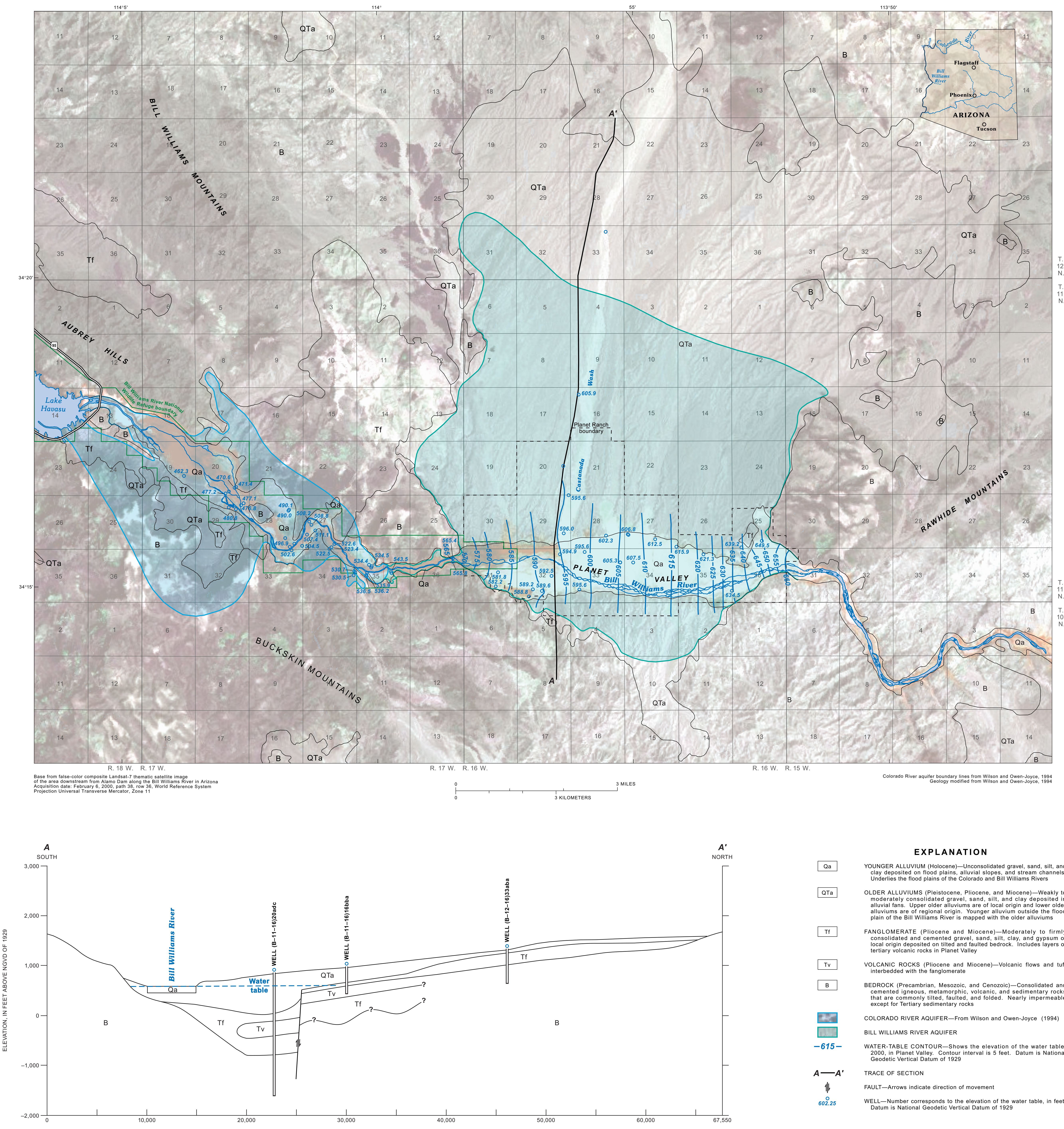

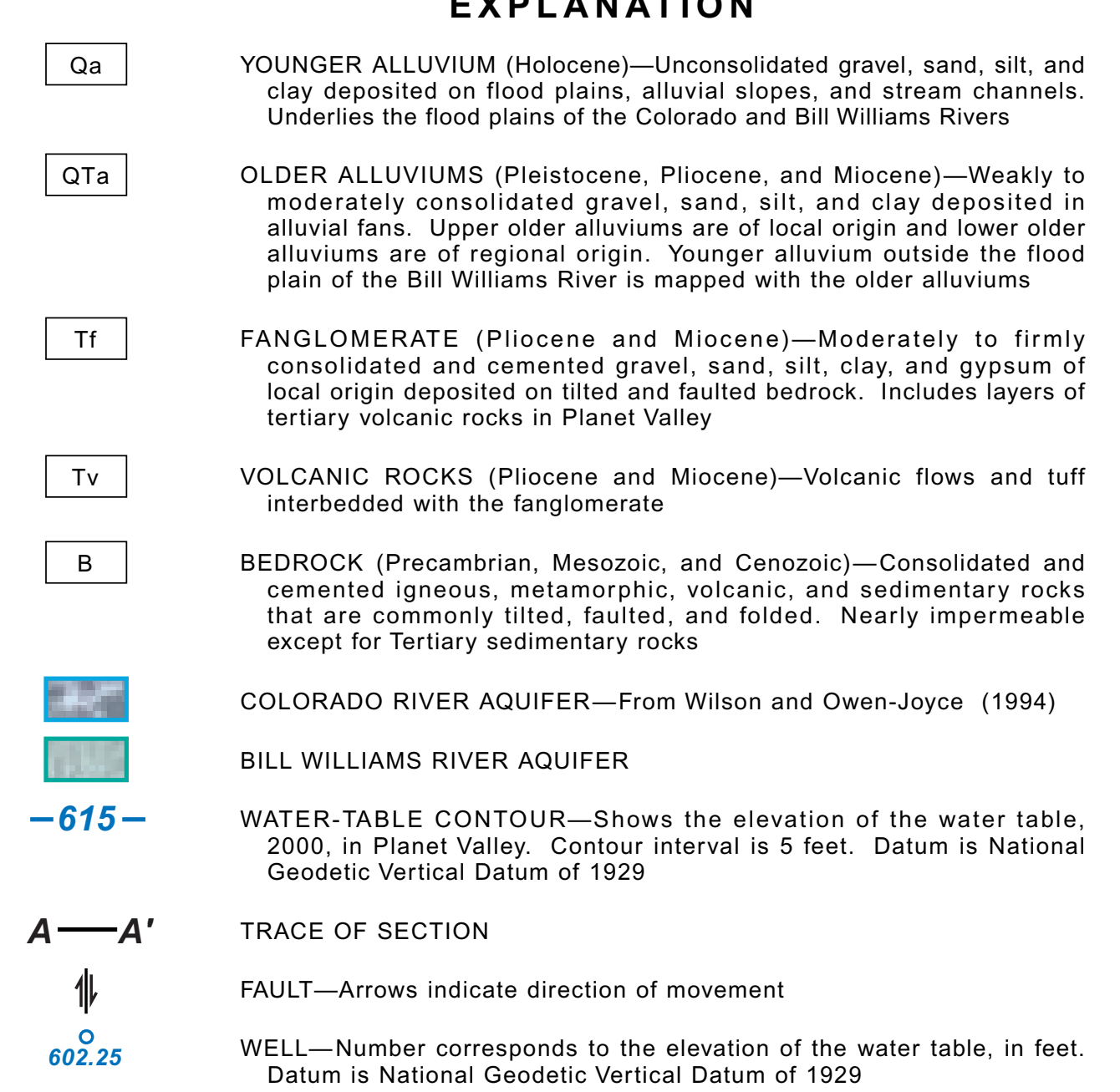

RIVER AQUIFERS AND ELEVATION OF THE WATER TABLE ALONG THE BILL WILLIAMS RIVER, ARIZONA-2000

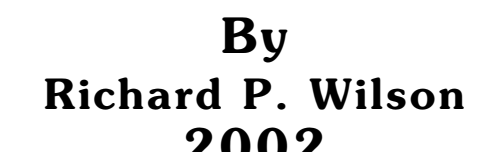

